to God Himself, as was most succinctly captured by the Sufi Ibn al-"Arabi in his dictum "freedom (hurriyyah) is slavery to God." It is when we are closest to God that we are truly free "from man's lordship over man".

Akyol defends the Mu'tazilite argument that man has free will and creates his own actions, which are not predetermined by God. Nevertheless, "environmental determinism" (131) is so powerful as to be able to "[shape] not just the mindsets of individuals and the culture of societies but also the political structures of states" (132-133). Is man free enough to resist divine determination, but helpless against his environment?

Akyol seems to take it for granted that the salvation of Muslims today lies in wise economic policies and social planning: in other words, seeking solutions to the challenges that lie outside man, not those that are within him. One may argue that such an external basis for freedom is at best unstable and at worst precarious.

Islam is precisely a force to enable individuals to remain righteous and ethical despite economic hardship. A moral and just society dependent on economic stability offers only a false sense of security and a fragile basis for a moral order. The Quranic attitude is seen in its challenging of the Makkan practices of burying babies alive on account of poverty (al-Nahl, 16:58-59), asking instead for them to put their trust in Allah (al-'Isra', 17:31), offering neither pennies nor policies but quite simply hope. To lapse into crime and immorality as a result of poverty suggests the failure, not merely of policy but of remaining true to absolute moral constraints enshrined by religion.

Nevertheless, despite caveats, in the book Islam without Extremes: a Muslim Case for Liberty, Akyol's analysis of the Turkish Islamo-liberal experiment remains compelling.

\title{
R. Skidelsky and C. W. Wigström, Eds., The Economic Crisis and the State of Economics
}

(New York: Palgrave Macmillan, 2010), 140 pp., ISBN 978-0-230-10254-5.

\section{Abdul Karim Abdullah, IAIS Malaysia}

The Economic Crisis and the State of Economics, published by Palgrave Macmillan in 2010, is a product of a symposium held with the purpose of identifying the causes of the current financial crisis as well as prescribing remedies. Robert Skidelsky, organiser of the symposium, is a British economic historian, former politician, and author of the acclaimed three-volume biography of J. M. Keynes. He is Emeritus Professor of Political Economy at the University of Warwick, UK. Christian Westerlind Wigström is a graduate student of philosophy at Merton College, Oxford. 
The symposium was "inspired by a dissatisfaction with the silence of the economics profession on the causes of the current economic downturn and the remedies for overcoming it," writes Skidelsky. "Here was an event that was freely compared to the Great Depression, but comments in the financial press were being provided entirely by financial journalists. Where were the economists?" (ix). On 13 February 2009, "some of the best of the economists" (ix) met at the House of Lords, London, UK. The participants came from diverse backgrounds: academic, business, and government. This diversity gives the book an interdisciplinary character.

The discussion centred on three themes: risk and uncertainty, macroeconomics and ethics. The "efficient market hypothesis" (EMH) in particular received a significant amount of attention. The EMH became popular beginning in the mid 1960s, during a period known as "financialisation" (1960s onwards). Financialisation is the growth of the finance sector at the expense of the real sector.

According to the EMH, markets are efficient. But they are not efficient in the customary (economic) sense in the way they allocate resources. Markets are efficient because they determine prices, in particular the prices of securities, accurately. Determining prices and allocating resources, however, are two very different things. Achieving the former does not necessarily guarantee achieving the latter.

Viewing markets as efficient on account of their ability to establish prices accurately is the sense in which the term efficient is used in finance. It is in this sense that this term is also used in the discussion. It would appear that even intellectual discourse is not exempt from being influenced by financialisation.

The 2008 global financial crisis showed that markets were not efficient, the participants noted, because prices of securities, in particular the collateralised debt obligations (bundles of debt), collapsed dramatically.

However, it is hard to see how a narrow notion of efficiency such as that used in finance can be of much help in solving problems that extend beyond losses experienced by investors. Larger problems - such as a misallocation of resources - affect the entire society rather than only a part of it, the investors.

Moreover, it appears that the contributors intended the characterisation of markets as inefficient to apply to all markets, including the real sector markets. Characterising real sector markets (including the stock market) as inefficient, however, on the basis of what happened primarily in the credit markets, may be premature. There is a major difference between real sector markets and credit markets.

The reason for this difference is that credit markets and real sector markets operate in radically different ways. Activity in the credit markets is driven by an incentive in the form of interest. Activity in the real sector is driven by an incentive in the form of profit.

Despite appearances, interest and profit constitute fundamentally different incentives. Contracts in which these incentives are paid by one counterparty to 
the other establish radically different relationships between counterparties. The differences in the terms on which capital is provided to entrepreneurs by investors or lenders, respectively, result in significant differences in the way resources will be allocated. Profit is an excellent incentive for ensuring efficiency in the real sector, assuming competitive conditions and the absence of regulatory and market failure. Interest is not.

Approximately two-thirds of all business financing takes place in the form of debt. Thus, how the greater part of the resources will be allocated in the real sector depends first of all on how resources are allocated in the credit sector. Any misallocation of resources in the credit sector will cause a corresponding misallocation of resources in the real sector. This is what happened in the 2008 global financial crisis. For this reason, failures in the credit markets should not be interpreted as failures of the real sector markets.

Evidence of inefficiency in the real sector showed up in the construction of millions of houses, financed with subprime loans, for which in the end there were no buyers. When subprime borrowers eventually defaulted on their housing mortgages, the houses were repossessed by financial institutions and are now being torn down due to dilapidation. This constitutes clear evidence of waste on a massive scale. Thus, it is clear that failure in the credit markets did not only take the form of the inability to indicate prices of securities accurately. It also took the form of a failure to allocate resources efficiently.

In Shakespeare's Hamlet, Claudius observes, "Diseases desperate grown, by desperate appliances are relieved, or not at all" (IV, iii). There is no doubt that a desperate disease, an economic depression, is afflicting the modern financial and economic system. However, while there is agreement on what the disease is, there is less agreement on what caused the disease, and still less agreement on how to cure it. The major reason for this impasse is that analysis, whether of problems, causes or solutions, continues to take place within the proverbial box, in the confines of the dominant intellectual paradigm.

This paradigm takes for granted that lending at interest is not only an efficient but also an ethically acceptable way of financing, whether of investment, consumption or government spending. A closer look, however, shows that interest-based financing constitutes a major anomaly within the free enterprise system. The main reason is that the earning of income by mere lending contradicts one of the most basic principles of the free enterprise system, if not also of justice. This principle is that reward needs to be linked, and indeed be proportionate, to performance.

Unlike payments of dividends to investors, payments of interest to creditors do not depend on the efficiency (productivity) of the enterprises they finance. Neither do they depend on the total amount of profit earned. Rather, they depend on the total amount of capital supplied (loaned), as well as on the rate of interest charged. Thus, in financing business investment by lending at interest, the 
reward (interest) paid to creditors is not linked in any way to the performance (profitability) of the business. Moreover, the amount of interest to be paid to lenders is determined even before it is ascertained whether the enterprise utilising loan financing has earned any profits to begin with.

As a result, lenders have little incentive to channel funds to enterprises that are more efficient (profitable) than what it takes to repay loans with the interest. Moreover, because many loans are secured with collateral, lenders have little incentive to perform due diligence to ensure that any proposed projects (such as the construction of subprime houses) are commercially viable over the longer term. This is due to the perception that they face little or no risk, as the loans are "collateralised". One consequence of the absence of the link between compensation and performance, as well as the perception that lenders faced little or no risk, was a misallocation of resources on a scale hardly seen before.

To prevent a repeat of this fiasco, decisions on how resources are allocated in the real sector have to be made in the real sector rather than in the credit sector. This requires taking the decisions on how to allocate resources out of the hands of the credit sector and entrusting them to the real sector. This can be achieved by phasing out interest-based financing and replacing it with profit and loss sharing.

The book concludes with an essay on morals. This would have been a good place to ask whether interest-based financing is ethical. But this does not happen. Instead, we are alerted to the fact that capitalism is in a "moral crisis" (119). Yet it is not capitalism that is in a crisis, but rather the people, businesses, and entire nations that are deeply in debt, and unable to come out of it.

In his General Theory Keynes wrote: "The difficulty lies, not in the new ideas, but in escaping from the old ones, which ramify, for those brought up as most of us have been, into every corner of our minds" (Preface, The General Theory of Employment, Interest, and Money, 1935). The best way we can learn from Keynes is to follow his advice and escape from some old ideas. In this case, however, we need to escape from his ideas, in particular his ideas about usury.

It is time to consider alternative, less damaging and unjust modes of financing: interest-free financing. This can be done by adopting bona fide Islamic financing, not the instruments that replicate conventional bonds, and thus also their weaknesses, in particular indebtedness and the risk of default. It is too late for Keynes to benefit from his own advice. It is not too late, however, for those who still think that the analytical framework in which he operated, and indeed helped to design, is capable of producing a solution to the current crisis.

One of the "most fruitful results" of the discussions, Skidelsky observes, "was the widespread agreement" on the need for new economic models (9). The interestfree financing system may be just such a model. It is worth exploring. It may just provide the type of cure spoken of by King Claudius in Shakespeare's Hamlet. 